\title{
TEMPERATURE AND MODIFIED ATMOSPHERE AFFECT THE QUALITY OF OKRA
}

\author{
Fernando Luiz Finger*; Maria Edith Della-Justina; Vicente Wagner Dias Casali; Mário Puiatti \\ UFV - Depto. de Fitotecnia - 36571-000 - Viçosa, MG - Brasil. \\ *Corresponding author <ffinger@ufv.br>
}

\begin{abstract}
Little information is available on the influence of temperature on plastic films wrapped okra (Albelmoschus esculentus) for their postharvested conservation. This works investigated the influence of the temperature and PVC film on the development of chilling injury and storability from one of the most popular Brazilian cultivar of okra cv. Amarelinho in fruits stored at $5,10^{\circ} \mathrm{C}$ and at $25^{\circ} \mathrm{C}$. Fruits were harvest at commercial maturity stage with length ranging from 8 to $12 \mathrm{~cm}$, and immediately wrapped in PVC over a polystyrene tray and than stored until visible deterioration or wilting symptoms. Lowering the temperature of storage room from 25 to 10 or $5^{\circ} \mathrm{C}$ decreased the weight loss in both PVC wrapped and control fruits, with a lower rate at $5^{\circ} \mathrm{C}$. By reducing the temperature to 5 or $10^{\circ} \mathrm{C}$ and wrapping the fruits in PVC film, the relative water content of the fruit pericarp was maintained throughout the storage, while at $25^{\circ} \mathrm{C}$ the high weight loss was associated with significant reduction of the water content. The development of chilling symptoms was delayed by the presence of PVC film in fruits stored at $5^{\circ} \mathrm{C}$. However, at $10^{\circ} \mathrm{C}$ symptoms of pitting were not developed in PVC wrapped or control fruits up to tenth day of storage. The rate of chlorophyll degradation was diminished by reducing the temperature and by wrapping the fruits with PVC film. The appearance of severe chilling symptoms at $5^{\circ} \mathrm{C}$ was associated to less chlorophyll in the fruit pericarp on the control as compared to their content in the PVC wrapped fruits.
\end{abstract}

Key words: Albelmoschus esculentus, chilling injury, PVC film, relative water content, chlorophyll

\section{TEMPERATURAEATMOSFERAMODIFICADA INFLUENCIAMA QUALIDADE DO QUIABO}

\begin{abstract}
RESUMO: Para o armazenamento do quiabo (Albelmoschus esculentus) há poucas informações disponíveis sobre a influência da temperatura e filmes plásticos na conservação pós-colheita desta hortaliça. Para investigar a influência da temperatura e do filme de PVC na qualidade e desenvolvimento de sintomas de injúria por frio de uma das mais populares cultivares brasileira de quiabo cv. Amarelinho, os frutos foram armazenados a 5,10 e $25^{\circ} \mathrm{C}$. Os frutos foram colhidos no estádio de maturação comercial, com comprimento entre 8 e $12 \mathrm{~cm}$, sendo então envoltos por uma camada de filme de PVC em bandeja de poliestireno expandido, seguido do armazenamento até o aparecimento de sintomas de deterioração ou murcha. A redução da temperatura de armazenamento de 25 para 10 ou $5^{\circ} \mathrm{C}$ diminuiu a perda de massa nos frutos envoltos com PVC e dos frutos controle, com menor taxa a $5^{\circ} \mathrm{C}$. Ao reduzir a temperatura para 5 ou $10^{\circ} \mathrm{C}$ e cobrir com filme de PVC, o conteúdo relativo de água foi mantido durante o armazenamento, porém a $25^{\circ} \mathrm{C}$ a elevada perda de massa esteve associada a significante redução do conteúdo de água do pericarpo do fruto. $\mathrm{O}$ aparecimento de sintomas de injúria por frio foi retardado pela presença de filme de PVC nos frutos armazenados a $5^{\circ} \mathrm{C}$. No entanto a $10^{\circ} \mathrm{C}$, não foram detectados sintomas de degeneração associados à injúria por frio nos frutos envoltos com PVC ou controle até o décimo dia de armazenamento. A taxa de degradação de clorofila durante o armazenamento foi menor nos frutos mantidos nas temperaturas mais baixas e com filme PVC. O aparecimento de sintomas severos de injúria por frio a $5^{\circ} \mathrm{C}$ relacionou-se com o menor conteúdo de clorofila dos frutos controle, quando comparado àqueles envoltos em filme de PVC.

Palavras-chave: Albelmoschus esculentus, injúria por frio, filme de PVC, teor relativo de água, clorofila
\end{abstract}

\section{INTRODUCTION}

Okra (Albelmoschus esculentus) is a well known tropical vegetable extremely popular on the diet of large part of human populations living in develop- ing countries. In Brazil, okra is used as an important ingredient in stews, soups or consumed as steamed vegetable. Commercially, fresh pods are usually marketed in open street markets or supermarkets without any kind of temperature or humidity control. Consum- 
ers identify the loss of fruit quality by the external yellowing and by the toughening or lack of tissue rupture of the apical pod when twisted with the fingers.

The fresh pods of okra have an extremely short shelf life mainly due to high respiration and water loss rates (Tamura \& Minamide, 1984). Although the water is the major component of fruits and vegetables, water loss of 5 to $10 \%$ can cause reduction quality showing shriveling and toughening of the tissues on most of them. Furthermore, as many other fruits and vegetables originated from tropical and subtropical regions, okra suffers chilling injury if stored below certain critical temperature. However, there are only few experiments showing the influence of storage temperature on the development of chilling injury on this vegetable. Okra should be stored at temperatures above to $9^{\circ} \mathrm{C}$ in order to avoid the development of chilling injury disorder, which includes pitting and discoloration (Lyons \& Breidenbach, 1987; Salunkhe \& Desai, 1984). Baxter \& Waters Jr. (1990) successfully stored pods of okra for 12 days at $11^{\circ} \mathrm{C}$ without development of chilling injury symptoms in the American breed cultivar. But, for one of the most popular cultivar grown in Brazil, no previous work was done to evaluate its sensibility to dehydration and chilling injury.

Either by increasing the $\mathrm{CO}_{2}$ and by reducing the $\mathrm{O}_{2}$ at storage atmosphere or by decreasing the rate of water loss from the product, an alleviation of the chilling symptoms can be observed in fruits stored under chilling inducing temperatures (Thompson, 1998). In banana, the modified atmosphere generated by wrapping bananas in non-perforated polyethylene bags resulted in less visible symptoms of chilling when compared with control fruits (Nguyen et al., 2004). Similar results in reducing the chilling development were observed in grapefruit coated with different kinds of commercial waxes on fruits stored at $4^{\circ} \mathrm{C}$ for two months (Dou, 2004).

This paper presents results of one experiment designed to evaluate the influence of temperature and film wrap on the weight loss, relative water content, chlorophyll degradation and development of chilling injury symptoms on fresh pods of okra.

\section{MATERIAL AND METHODS}

Okra fruits cv. Amarelinho with length ranging from 8 to $12 \mathrm{~cm}$ were harvested at Viçosa (652 m a.s.l., $20^{\circ} 45^{\prime}$ S e $42^{\circ} 51^{\prime}$ 'W), Minas Gerais State, Brazil, brought to the laboratory, cleaned with wet cloth and allowed to air dry. About $250 \mathrm{~g}$ of fruits were arranged in polystyrene trays over wrapped with polyvinyl chloride (PVC), while the control fruits were kept in open trays. All treatments were placed at temperatures of $5^{\circ} \mathrm{C}, 10^{\circ} \mathrm{C}$ with relative humidity of $95 \%$ and at $25^{\circ} \mathrm{C}$ with $85 \%$ relative humidity.

The water content on the pod pericarp was measured by the relative water content (RWC) of 0.8 $\mathrm{cm}$ diameter disks, which were saturated with water in moistened absorbent tissue paper, followed by drying the disks in an oven at $65^{\circ} \mathrm{C}$ until constant weight was achieved (Catsky, 1974). The RWC of the pericarp disks were estimated according to the formula as follow: RCW = Fresh weight - (dry weight) [(Saturated weight - dry weight) $]^{-1}$.

Total chlorophyll of the pod pericarp was extracted with $80 \%$ acetone and estimated at spectrophotometer at 645 and $663 \mathrm{~nm}$, according to the method described by Arnon (1949). Weight loss from each treatment was measured by weighting every day the trays and the data were expressed as percentage of loss from the initial fresh weight.

Chilling injury incidence on the pod surface is manifested as pitting spots associated with a brownish discoloration. The severity of symptoms was visually estimated using the follow ranging stages: 0 , absence of symptoms; 1 , less than five brown pitting spots; 2, more than five and less than ten brown spots; 3 , more than ten and less than fifteen brown spots; and 4, more than fifteen brown spots.

Trays were arranged in a completely randomized design with four replicates containing at least ten fruits each tray. The data were subject to analyses of variance using the SAEG software (UFV) tested at the $5 \%$ probability level. Regression modules were applied for the weight loss and relative water content of the fruits, selecting the models based on biological significance and higher $\mathrm{R}^{2}$.

\section{RESULTS AND DISCUSSION}

Regardless the storage temperature or the wrapping in the PVC film the storage weight loss rate was linear, showing higher weight loss rates with the increase in storage temperature, in both PVC wrapped and control fruits (Figure 1). Accumulated weight losses of $10 \%$ or higher caused freshness loss which was identified by the lack of tissue rupture when the pod tip was twisted. Storing the fruits at $25^{\circ} \mathrm{C}$ and 85\% RH without PVC film reduced freshness before completing the second day of storage (Figure 1). Only by PVC wrapping, the increase in the fruit shelf life was extended by at least 3-fold and the freshness losses were evident after seven days of storage (Figure 1). Such alternative is feasible for the Brazilian market current characteristics, because in most of the retail stores little refrigeration facilities are available ei- 
ther for okra or other vegetables, mainly due to their low commercial value when compared to imported fruits like apples, peaches, pears, grapes and plums.

Lowering the temperature of storage from 25 to 10 or $5^{\circ} \mathrm{C}$ reduced the weight loss in both PVC wrapped and control fruits. Ten days after harvest the weight loss was under $5 \%$ for those fruits stored at 10 or $5^{\circ} \mathrm{C}$ plus PVC, while the freshness losses for the unwrapped fruits started on the third and fifth day, respectively (Figure 1). Similarly to okra, PVC film significantly reduced the weight loss of strawberry and sweet cherry, both in cold storage and room temperature, extending their shelf life (Çelikel et al., 2003a; Çelikel et al., 2003b).

Except for the fruits stored at 5 and $10^{\circ} \mathrm{C}$ and wrapped with PVC, the continuous weight loss through storage affected the relative water content of the fruit pericarp in all remaining treatments, which
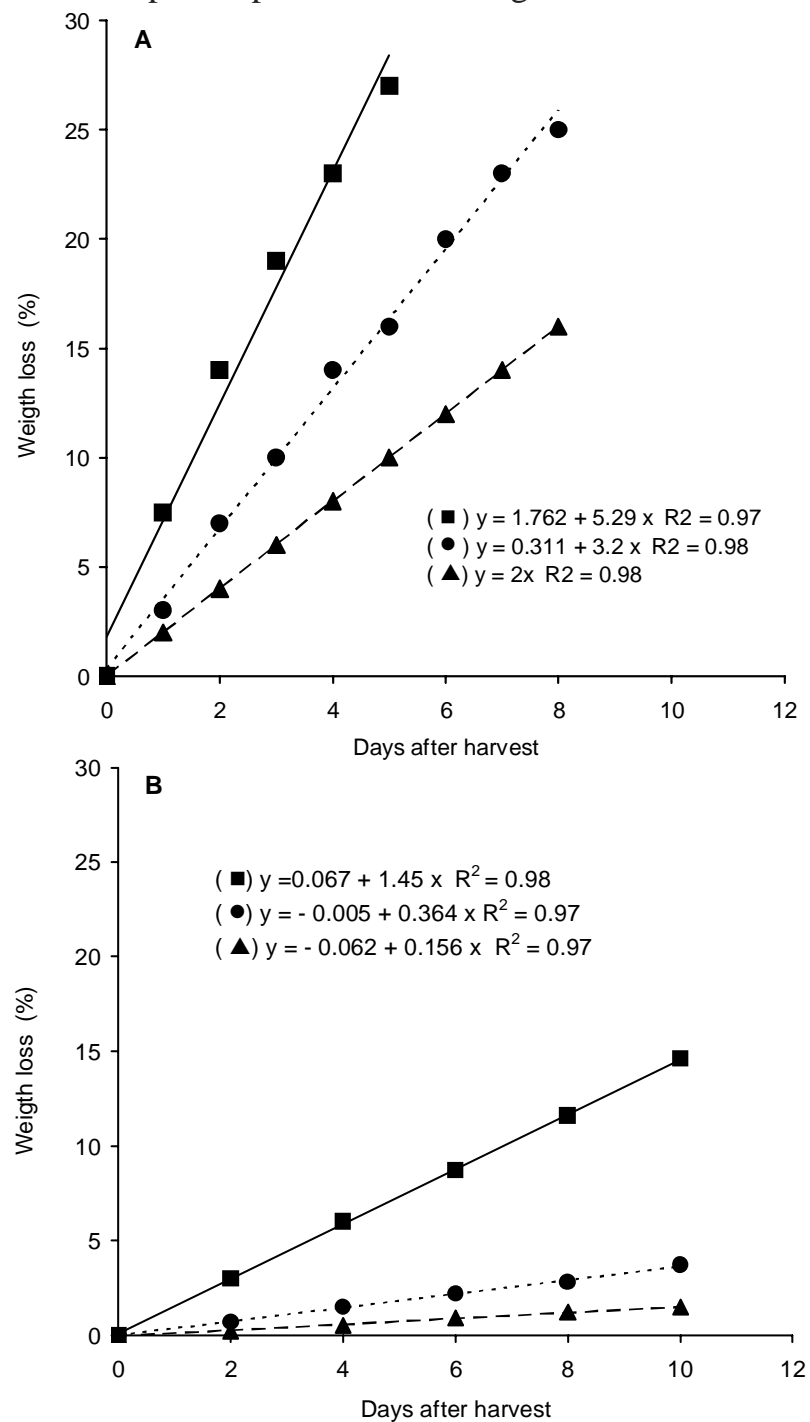

Figure 1 - Fresh weight loss of okra stored at $5(\mathbf{\Delta}), 10(\bullet)$ and $25^{\circ} \mathrm{C}(\mathbf{\square})$ for the control (A) and PVC wrapped fruits (B). declined more intensely in those fruits with higher rates of weight loss (Figures 1 and 2). The highest trend of water loss was observed in fruits stored at $25^{\circ} \mathrm{C}$ without PVC, followed by those wrapped with PVC, accounting for water losses of 2.651 and $1.105 \%$ per day, respectively (Figure 2). In kiwifruit, the relative water content of the outer pericarp also showed continuous decrease after harvest when the fruits were placed in ventilated chambers at room temperature (Burdon \& Clark, 2001). The relative water content for the fruits stored at 5 or $10^{\circ} \mathrm{C}$ and PVC film wrapped remained almost unchanged, because only $2.0 \%$ of the water was lost in ten days of storage. But, if the storage temperature was kept at $25^{\circ} \mathrm{C}$, the influence of the PVC film was less efficient in maintaining the water within the tissues, because near $13 \%$ of water from the fruits were lost in ten days (Figure 2). Thus, by measuring the lowering of the temperature
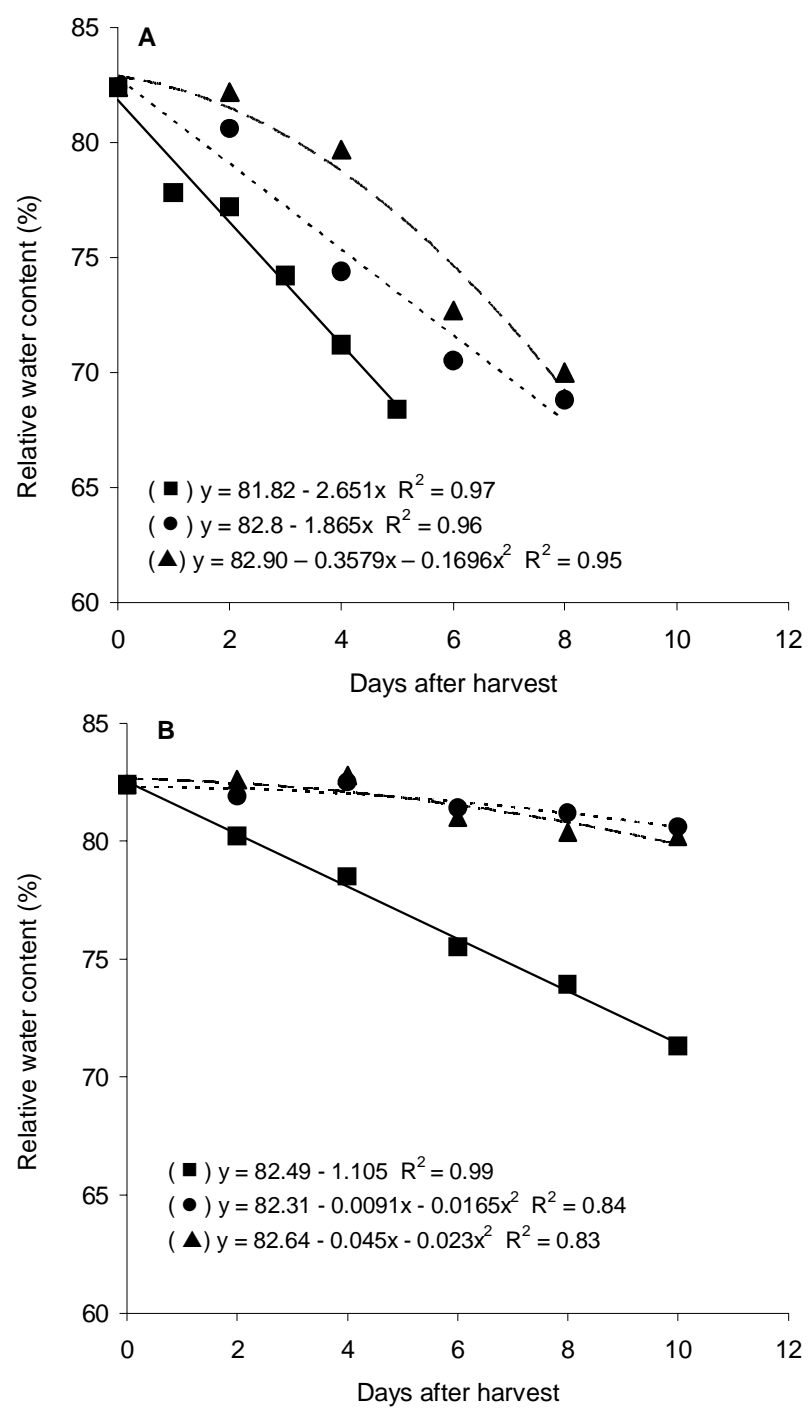

Figure 2 - Relative water content of okra stored at $5(\mathbf{A}), 10(\bullet)$ and $25^{\circ} \mathrm{C}(\boldsymbol{\square})$ for the control (A) and PVC wrapped fruits (B). 
and by the wrapping the okra with PVC, their initial water status was kept throughout the whole storage period.

The development of chilling symptoms in okra stored at $5^{\circ} \mathrm{C}$ was inhibited by the presence of PVC film (Figure 3). The maximum severity of symptoms - grade 3 - developed in fruits stored at $5^{\circ} \mathrm{C}$ was showed by the intense pitting spread over the whole pod surface (Figure 4B). The PVC film delayed the development of pitting at fruit surface until the forth day of storage, while on the unwrapped fruits, the surface pitting started on the second day after harvest (Figure 3). However, no pitting symptoms developed in fruits stored at $10^{\circ} \mathrm{C}$ in both PVC wrapped and un-

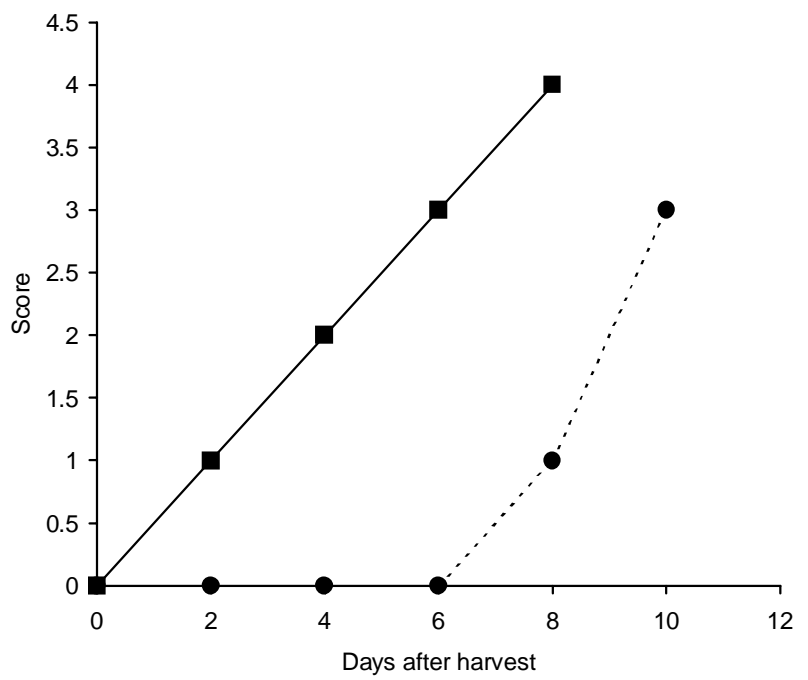

Figure 3 - Chilling injury development in okra stored at $5^{\circ} \mathrm{C}$ for

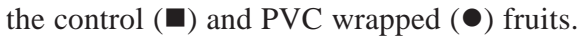

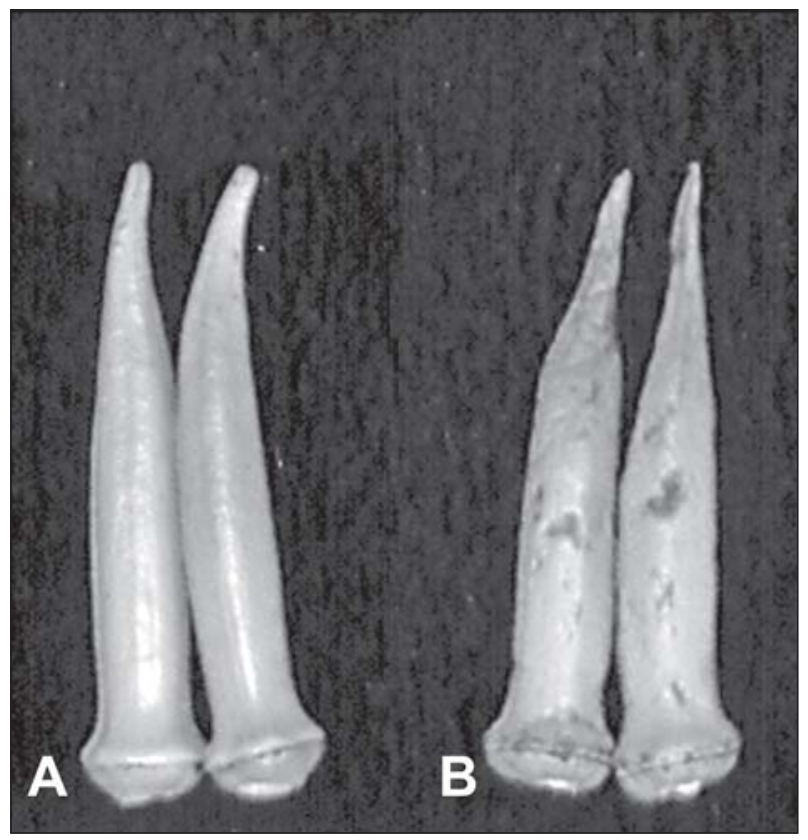

Figure 4 - Fresh (A) and chilling injured (B) okra fruit. wrapped okra throughout the ten days of storage (data not shown). Similar to okra, modifying the atmosphere by packing or coating the fruits reduces the low temperatures chilling effects on bananas and grapefruit, respectively (Nguyen et al., 2004; Dou, 2004). Storing peppers under chilling inducing temperatures at $1^{\circ} \mathrm{C}$, but wrapping with perforated and non-perforated polyethylene bags, delayed the development of the symptoms in both with higher benefits for the perforated bags (Kosson, 2003). However, in sweet basil, the storage of cuttings under controlled-atmosphere had no effect in alleviating the development of chilling at $5^{\circ} \mathrm{C}$ (Lange \& Cameron, 1998). The responses of fruits and vegetables to chilling inducing temperatures and the influence of controlled atmospheres on the development of symptoms are extremely variable and strongly dependent of the species genetic basis (Watkins \& Pritts, 2001). In American okra cultivars, the storage in polyethylene bags at $3^{\circ} \mathrm{C}$ also had similar effect in reducing the symptoms of chilling if compared to boxed pods (Perkins-Veazie \& Collins, 1992).

The temperature and the PVC affected the rate of chlorophyll degradation of the okra pods. Higher decrease in chlorophyll concentration was observed in those fruits stored at $25^{\circ} \mathrm{C}$ without the presence of the PVC film, followed by the fruits wrapped in PVC (Figure 5). The lowest rates of chlorophyll degradation were detected in fruits stored either at 5 or $10^{\circ} \mathrm{C}$ wrapped with PVC film, which showed similar trends in both temperatures, dropping the chlorophyll content from 35 to $31 \mu \mathrm{g} \mathrm{g}^{-1} \mathrm{FW}$ from harvest to the tenth days of storage (Figure 5). However, higher rates of pigment breakdown were detected when the fruits were kept without PVC, falling to 23 and $27 \mu \mathrm{g} \mathrm{g}^{-1}$ FW by the eight day after harvest at both 5 and $10^{\circ} \mathrm{C}$, respectively (Figure 5). Thus, regardless the temperature of storage, the PVC film was enable to reduce the rate of chlorophyll breakdown in okra, but for the unwrapped fruits, the temperature of $5^{\circ} \mathrm{C}$ hastened the chlorophyll degradation.

\section{CONCLUSIONS}

The PVC film is effective in reducing the weight loss and keep the water content of okra regardless the temperature of storage used. The modified atmosphere induced by the PVC film reduces the chilling injury development in fruits stored at a damaging temperature of $5^{\circ} \mathrm{C}$. Storing the fruits at $25^{\circ} \mathrm{C}$ induces quick chlorophyll degradation, which is avoided by lowering the temperature to 5 or $10^{\circ} \mathrm{C}$ and wrapping them with PVC film. The appearance of severe chilling symptoms is associated to lower chlorophyll content in the fruit pericarp. 

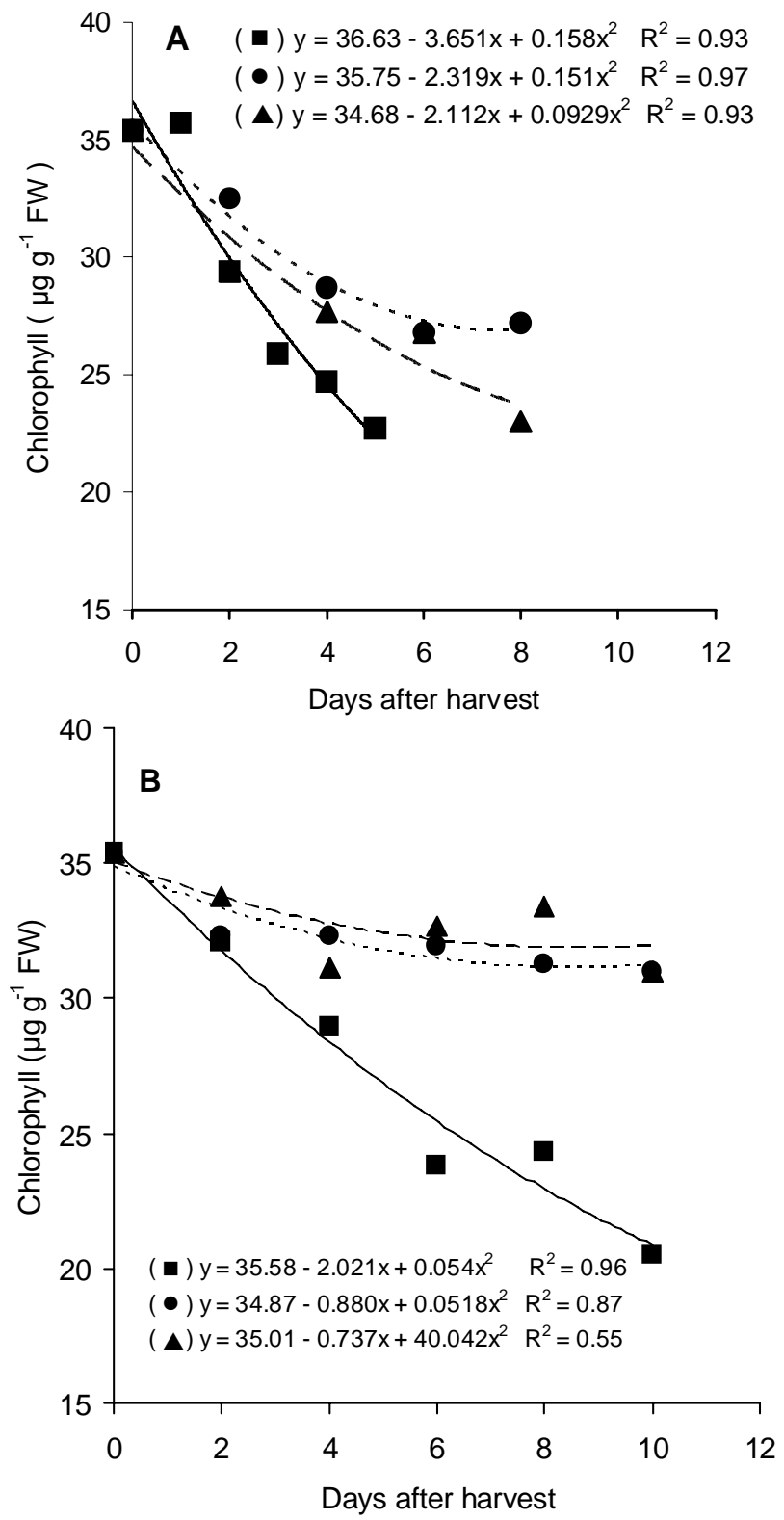

Figure 5 - Chlorophyll content of okra stored at $5(\mathbf{\Delta}), 10(\bullet)$ and $25^{\circ} \mathrm{C}(\boldsymbol{\square})$ for the control (A) and PVC wrapped fruits (B).

\section{ACKNOWLEDGEMENTS}

The authors gratefully thank the scholarships granted by CNPq and CAPES.

\section{REFERENCES}

ARNON, D.I. Copper enzymes in isolated chloroplasts: polyphenoloxidase in Beta vulgaris. Plant Physiology, v.24, p.1-15, 1949.

BAXTER, L.; WATERS JR., L. Chemical changes in okra stored in air controlled atmosphere. Journal of the American Society for Horticultural Science, v.115, p.452-454, 1990.

BURDON, J.; CLARK, C. Effect of postharvest water loss on 'Hayward' kiwifruit water status. Postharvest Biology and Technoogy, v.22, p.215-225, 2001.

CATSKY, J. Water content. In: SLAVIK, B. (Ed.) Methods of studying plant water relations. Berlin: Springer, 1974. p.121131.

ÇELIKEL, F.G.; KAYNAS K.; ERENOGLU, B. A study on modified atmosphere storage of strawberry. Acta Horticulturae, v.628, p.423-430, 2003a.

ÇELIKEL, F.G.; ÖZELKÖK S.; BURAK, M. A study on modified atmosphere storage of sweet cherry. Acta Hortiulturae, v.628, p.431-438, 2003b.

DOU, H. Effect of coating application on chilling injury of grapefruit cultivars. HortScience, v.39, p.558-561, 2004.

KOSSON, R. Chlorophyll fluorescence and chilling injury of green pepper as affected by storage conditions. Acta Horticulturae, v.628, p.379-385, 2003.

LANGE, D.L.; CAMERON, A.C. Controlled-atmosphere storage of sweet basil. HortScience, v.33, p.741-743, 1998.

LYONS, J.M.; BREIDENBACH, R.W. Chilling injury. In: WEICHMANN, J. (Ed.) Postharvest physiology of vegetables., New York: Marcel Dekker, 1987. p.305-326.

NGUYEN, T.B.T.; S. KETSA, S.; DOORN, W.G. van. Effect of modified atmosphere on chilling-induced peel browning in banana. Postharvest Biology and Technoogy, v.31, p.313317, 2004.

PERKINS-VEAZIE, P.; COLLINS, J.K. Cultivar, packing and storage temperature differences in postharvest shelf life of okra. HortTechnology, v.2, p.350-352, 1992.

SALUNKHE, D.K.; DESAI, B.B. Postharvest biotechnology of fruits. Boca Raton: CRC Press, 1984. v.2, 147p.

TAMURA, J.; MINAMIDE, T. Harvesting maturity, handling, and storage of okra pods. Bulletin of the University of Osaka Prefecture. Series B, v.36, p.87-97, 1984.

THOMPSON, A.K. Controlled atmosphere storage of fruits and vegetables. Wallingford: CABI, 1998. 278p.

WATKINS, C.B.; PRITTS, M.P. The influence of cultivar on postharvest performance of fruits and vegetables. Acta Horticulturae, v.553, p.59-63, 2001.
Received February 06, 2007

Accepted November 14, 2007 